\title{
A clinical study of endodontically treated and prosthodontically restored teeth
}

\author{
Studiu clinic privind reconstrucția protetică a dinților tratați endodontic
}

\author{
Smaranda Dana Buduru'1, Andreea Prigoană², Oana Baru², Manuela Manziuc', \\ Ioana Sofia Ciutrilẳ ${ }^{3}$, Anca Mesaroș ${ }^{4}$ \\ ${ }^{1}$ Disciplina Protetică dentară, UMF „Iuliu Hațieganu“, Cluj-Napoca, România \\ ${ }^{2}$ Clinica Stomatologică Stomestet, Cluj-Napoca, România \\ ${ }^{3}$ Disciplina Endodonție și Odontoterapie Restaurativă, UMF „Iuliu Hațieganu“, Cluj-Napoca, România \\ ${ }^{4}$ Disciplina Propedeutică și Estetică Dentară, UMF,Iuliu Hațieganu“, Cluj-Napoca, România
}

\begin{abstract}
The aim of this study was to assess the prevalence and type of prosthetic restoration of endodontically treated teeth, with or without reinforcement with fiber posts, in a descriptive observational study. Also, to consider different selection criteria regarding the choice of material used for the restorations and types of failures.

Material and method. 196 patients were included in the study, with a total of 566 endodontically treated teeth. The teeth were endodontically treated and prosthodontically restored, in a private dental clinic in Cluj-Napoca, during November 2015-November 2016. The data for the study was collected from the patients charts, using Microsoft Office Excel. Results. Most of the endodontically treated teeth are observed in the posterior area (73\%), both on the upper and lower arches. $51 \%$ of the restorations are porcelain fused to metal, followed by $34 \%$ all ceramic, $15 \%$ composite. Restorations made with acrylate are below 1\%. From 566 endodontically treated teeth and prosthodontically restored, only 21 showed a type of event, which was either fracture of the restoration (2 of the cases), or debonding (19 of cases). $38 \%$ of these events were found in composite bridges, $24 \%$ in composite crowns, $19 \%$ indirect temporary bridges, $14 \%$ in porcelain fused to metal crowns and only $5 \%$ inall ceramic crowns.

Conclusion. The frequency of the type of endodontic treatment is influenced by the type of tooth, and it's location. The decision of choosing beetween one or another type of restoration, considering the clinical situation, influences the succes rate of the restoration.
\end{abstract}

Keywords: endodontic treatment, fiber post, prosthodontic restoration, porcelain fused to metal, all ceramic, composite resins

\section{REZUMAT}

Scopul acestui studiu este de a urmări prevalența și tipurile de restaurări coronare în cadrul unui lot de dinți tratați en-dodontic, cu sau fără ranforsarea cu pivot din fibră de sticlă, într-un studiu descriptiv observațional. Adiacent, obiec-tivul acestui studiu este de a prezenta criteriile de selecție ale materialelor din care au fost realizate reconstrucțiile, dar și aspecte legate de eșecurile acestora.

Material şi metodă. Au fost introduși în studiu 196 de pacienți, având în total 566 de dinți tratați endodontic în cadrul unei clinici particulare de stomatologie din Cluj-Napoca, în perioada noiembrie 2015-noiembrie 2016. Pacienții incluşi în studiu au prezentat dinți tratați endodontic și restaurări coronare. Pentru a crea baza de date cu pacienţii incluşi în studiu, s-a folosit programul Microsoft Office Excel, luând în considerare datele menționate în fișele pacienților și radiografiile acestora.

Rezultate. Rezultatele statistice au relevat că predomină tratamentele endodontice la nivelul dinților laterali atât la nivelul arcadei maxilare, cât și la nivelul arcadei mandibulare, în proporție de $73 \%$. De asemenea, $51 \%$ dintre reconstrucțiile coronare sunt metalo-ceramice, $34 \%$ sunt integral ceramice, iar cele din rășini compozite sunt în proporţie de 15\%. Reconstrucțiile realizate prin intermediul acrilatelor autopolimerizabile sunt în proporţie nesemnificativă (sub 1\%). Din totalul de 566 de dinți devitali reconstituiți, doar 21 au înregistrat un anumit tip de accident, fie fractura reconstrucției (2 cazuri), fie descimentare (19 cazuri). Aceste accidente s-au produs la nivelul retentorilor în proteze parțiale fixe din rășini compozite $(38 \%)$, la nivelul coroanelor de înveliș din rășini compozite (24\%), la nivelul retentorilor în proteze parțiale fixe reconstituiți prin tehnica Scutan (19\%), la nivelul coroanelor de înveliș metalo-ceramice (14\%) și la nivelul coroanelor de înveliș integral ceramice (5\%).

Concluzii. Frecvența tipului de tratament endodontic diferă în funcție de tipul de dinte și localizarea acestuia, iar decizia de a reconstitui coronar, printr-o metodă sau alta, în funcție de situația clinică, influențează rata de succes a acestuia.

Cuvinte cheie: tratament endodontic, fibră de sticlă, reconstrucții protetice, metalo-ceramică, integral ceramică, răşini compozite 


\section{INTRODUCERE}

Analiza structurilor dentare restante ale dinților care urmează să fie trataţi endodontic este importantă pentru alegerea tipului de restaurare coronară, care trebuie să asigure rezistența la fractură a dinților restaurați. Rezultatele unui studiu arată că dinții cu toți pereții axiali intacți prezintă rezistența cea mai crescută la fractură. Dinții cu 1-2 pereți proximali sau peretele palatinal absent prezintă rezistența cea mai mică la fractură. În concluzie, există o corelație între cantitatea de țesuturi dure restante și rezistența la fractură a dintelui [1].

Din cauza faptului că dinţii devitali prezintă o cantitate mare de smalț afectat și subminat, simpla restaurare coronară este insuficientă pentru a asigura rezistența la forțele ocluzale. Pentru a crește această rezistență și a scădea riscul de fractură a dintelui restant, se plasează pivoți din fibră de sticlă pe unul sau pe mai multe canale, pivoţi care vor deplasa potențialul punct de fractură de la marginea gingivală a coroanei spre apex (vor prelua o parte dintre forțele ocluzale) [2].

Efectul de ferulă constă în existența unei încercuiri de 360 de grade pe care restaurarea protetică o realizează pe exteriorul pereților dentari restanți, pentru a crește rezistența complexului dinte-restaurare protetică. Acest principiu se bazează, de fapt, pe cantitatea de dentină sănătoasă rămasă după finisarea preparației pentru reconstrucție [3].

Deseori, situația clinică a dintelui tratat nu permite o încercuire completă de 360 de grade, cum ar fi ideal, însă, decât să avem lipsa totală a efectului de ferulă, se preferă o încercuire incompletă pentru un prognostic mai bun. Regiunile dentare unde se recomandă prezența unor structuri minime sunt: peretele vestibular (unde acționează forțe de compresiune) și peretele palatinal/lingual (unde acționează forțe de tracțiune) [4].

Scopul acestui studiu este de a urmări prevalența şi tipurile de restaurări coronare ale unui lot de dinţi tratați endodontic, cu sau fără ranforsarea cu pivot din fibră de sticlă, într-un studiu descriptiv observațional. Adiacent, obiectivul acestui studiu este de a prezenta criteriile de selecție a materialelor din care au fost realizate reconstrucțiile, dar și aspecte legate de eșecurile reconstrucțiilor.

\section{MATERIAL ŞI METODĂ}

Pentru a examina și a evalua diferite tipuri de reconstrucții la nivelul dinților tratați endodontic, au fost introduși în studiu 196 de pacienți, având în total 566 de dinţi devitali. Pacienții care au fost selectați, indiferent de vârstă sau sex, au fost tratați endodontic și restaurați protetic în cadrul unei clinici particulare de stomatologie din Cluj-Napoca, în perioada noiembrie 2015-noiembrie 2016. Pentru a crea această baze de date, s-a folosit programul Microsoft Office Excel, luând în considerare datele menționate în fișele pacienților și radiografiile acestora.

Parametrii urmăriți în acest studiu sunt următorii:

- Tipul de dinte

- Tipul de tratament endodontic realizat (per primam/retratament endodontic)

- Ranforsare sau nu, cu pivot din fibră de sticlă

- Tipul de reconstrucție

- Prezența unui eșec după finalizarea reconstrucției

Tipurile de reconstrucții realizate pe acești dinți devitalizaţi sunt:

- Reconstrucție directă cu răşini compozite

- Inlay din rășini compozite

- Inlay din ceramică emax

- Overlay din rășini compozite

- Overlay din ceramică emax

- Coroană de acoperire din rășini compozite

- Coroană de acoperire metalo-ceramică

- Coroană de acoperire integral ceramică (atât din zirconiu, cât și emax)

- Fațetă indirectă din rășini compozite

- Proteză parțială fixă realizată fie prin tehnica Scutan, fie din zirconiu, fie din rășini compozite

Cazurile au fost ţinute sub supraveghere 9 luni, urmărindu-se apariţia în timpa eventualelor eșecuri la nivelul lor. Pentru a observa accidentele survenite, de la cimentare până în momentul încheierii studiului, au fost analizate fişele pacienţilor, în care era consemnat statusul reconstrucțiilor la vizitele periodicede igienizare, prin intermediul examinărilor clinice și radiologice. S-au luat în considerare în calitate de accidente fractura reconstrucției și descimentarea. La încheierea studiului, datele culese au fost organizate, iar apoi au fost exprimate sub 
formă de grafice pentru a evidenția mai bine aspectele urmărite.

\section{REZULTATE}

La sfârşitul perioadei de observaţie (noiembrie 2016), informaţiile adunate au fost analizate şi supuse unor teste statistice. Diversitatea datelor a facilitat o mai bună stratificare a rezultatelor. S-a evidențiat distribuția dinţilor tratați endodontic și reconstituiți coronar la nivelul arcadei maxilare (Fig. 1) şi la nivelul arcadei mandibulare (Fig. 2).

S-a constatat faptul că, dintre cei 566 de dinți devitali, cele mai frecvente restaurări se regăsesc la nivelul dinţilor laterali, atât la arcada maxilară, cât și la cea mandibulară (Fig. 3).

De asemenea, s-a urmărit tipul de tratament endodontic realizat pe acești dinți (retratament sau tratament endodontic per primam). Se observă faptul că la nivelul dinților din arcada maxilară predomină tratamentele endodontice per primam (Fig. 4), iar la nivelul dinţilor din arcada mandibulară predomină retratamentele endodontice (Fig. 5).

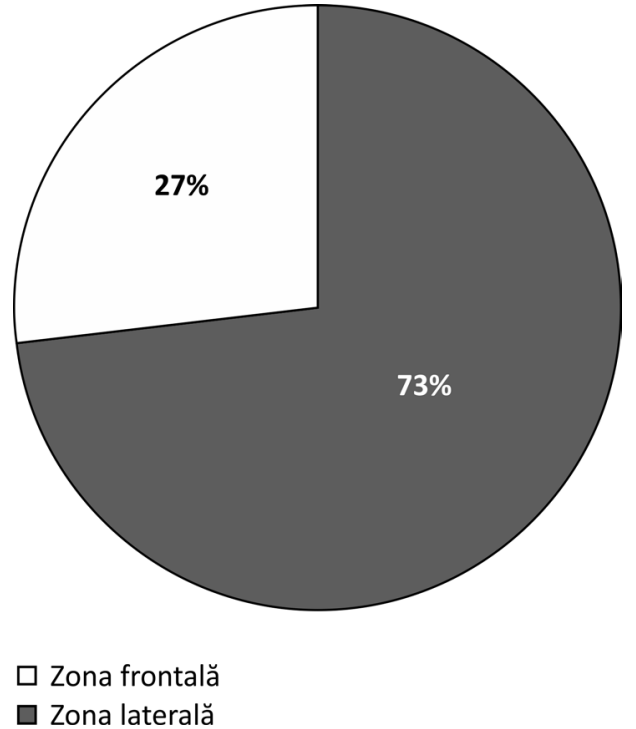

FIGURA 3. Frecvența dinților tratați endodontic în zona laterală şi în zona frontală

O diferență semnificativă observată la nivelul acestor dinți, pe care s-au realizat coroane de înveliș, este aceea că, în proporție de $99 \%$, aceştia au fost ranforsați (Fig. 6).

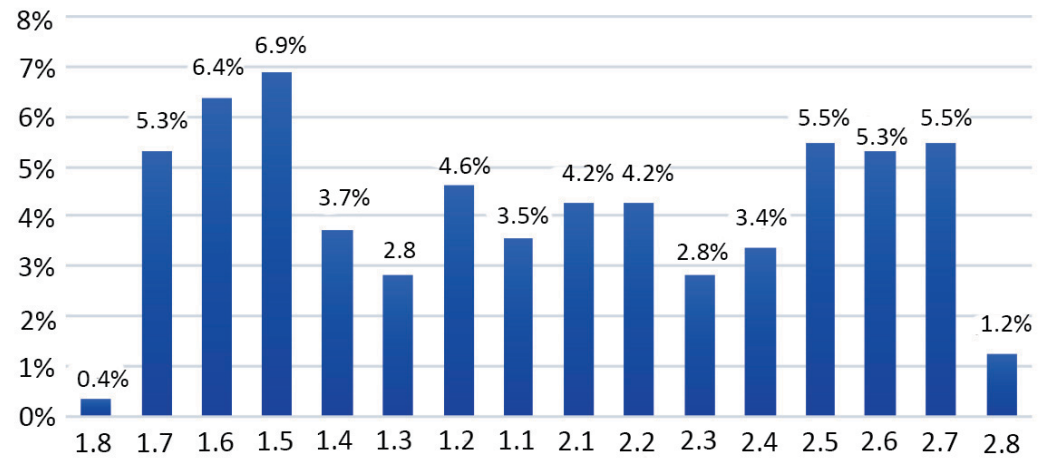

FIGURA 1. Distribuția dinților devitali reconstituiți la nivelul arcadei maxilare

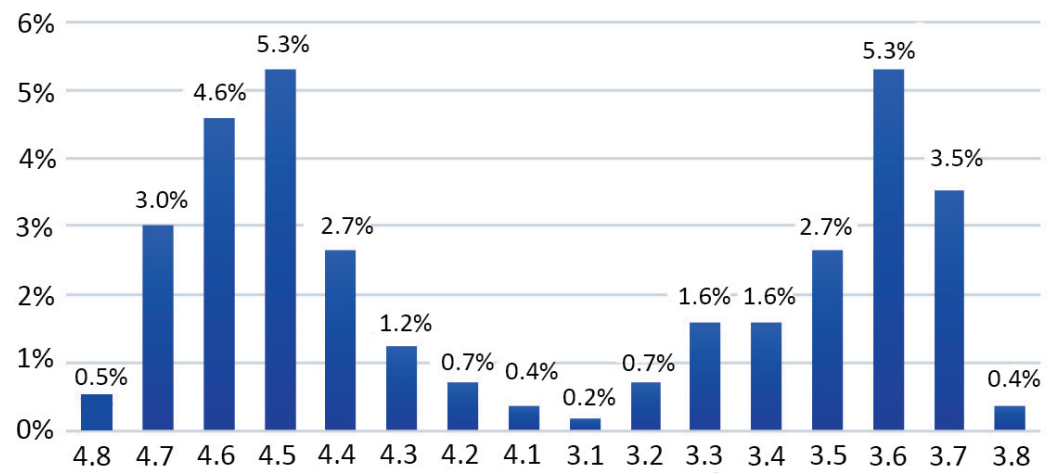

FIGURA 2. Distribuția dinților devitali reconstituiți la nivelul arcadei 


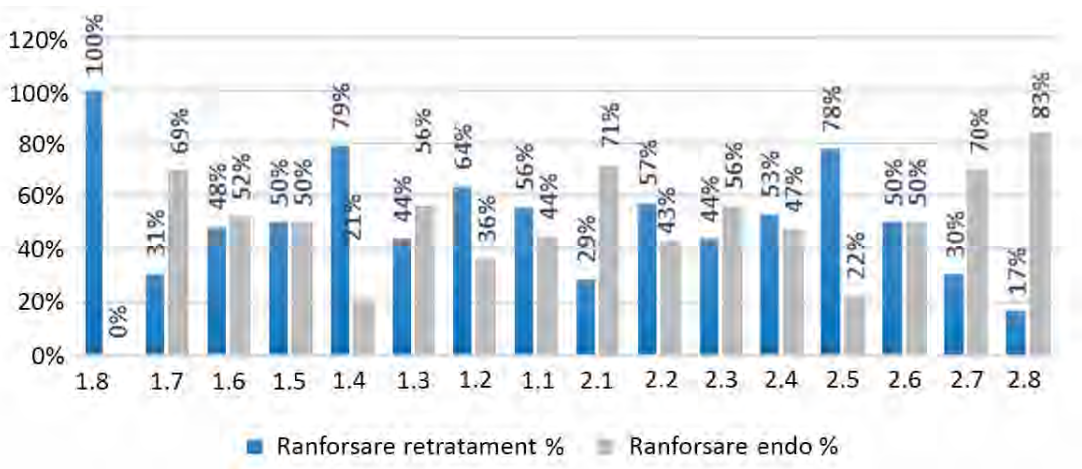

FIGURA 4. Frecvența tipului de tratament endodontic în funcție de dinte, la nivelul arcadei maxilare

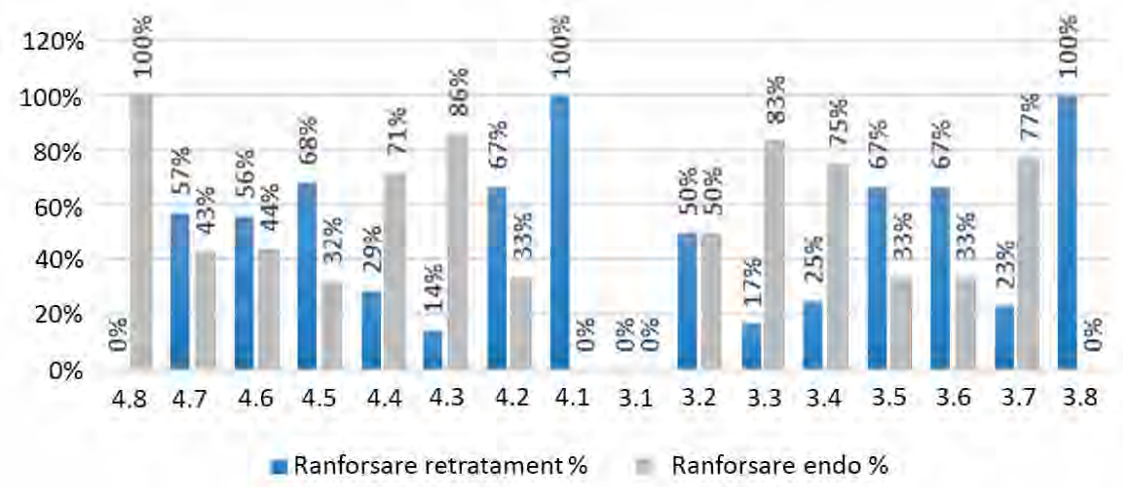

FIGURA 5. Frecvența tipului de tratament endodontic în funcție de dinte, la nivelul arcadei mandibulare

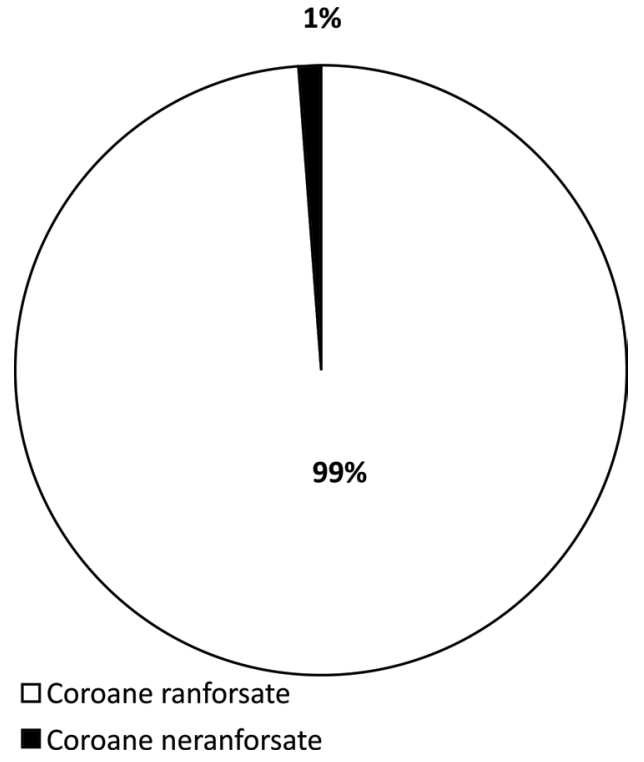

FIGURA 6. Frecvența ranforsării dinților reconstituiți cu coroane de acoperire

În continuare, s-a urmărit tipul de material utilizat pentru reconstrucția dinţilor incluşi în studiu. Indiferent de tipul de reconstrucție, s-au identificat patru tipuri de materiale: rășini compozite, metaloceramică, integral ceramică (zirconiu și emax) şi acrilat autopolimerizabil. Rezultatele arată faptul că $51 \%$ dintre reconstrucții sunt metalo-ceramice, $34 \%$ sunt cele integral ceramice şi $15 \%$ cele din rășini compozite. Reconstrucțiile realizate prin intermediul acrilatelor autopolimerizabile sunt în proporţie nesemnificativă (sub 1\%) (Fig. 7).

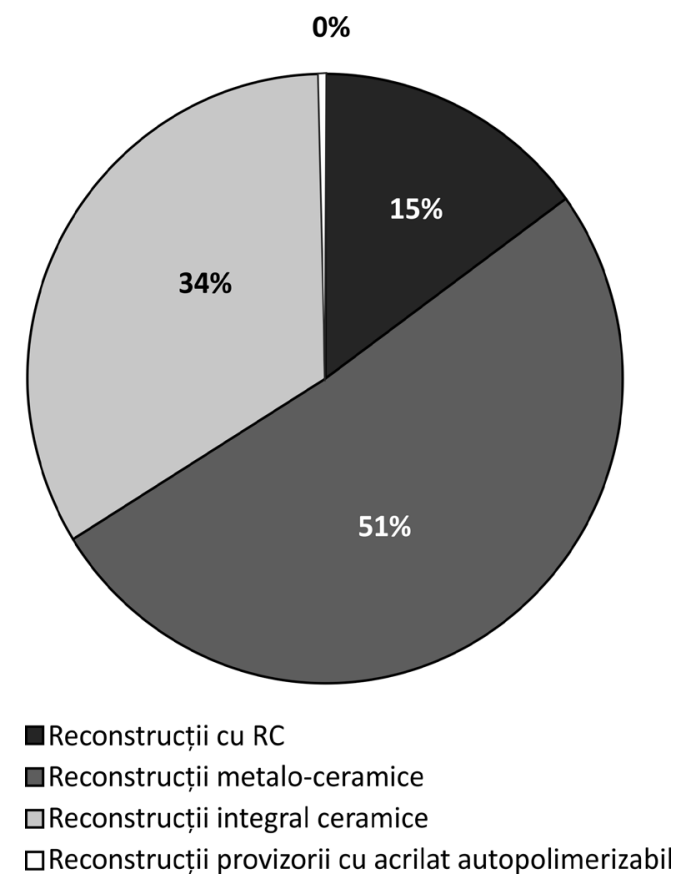

FIGURA 7. Frecvența tipului de material utilizat pentru reconstrucția dinților devitali

Luând în considerare tipurile de reconstrucții realizate pe acești dinți trataţi endodontic, am obser- 


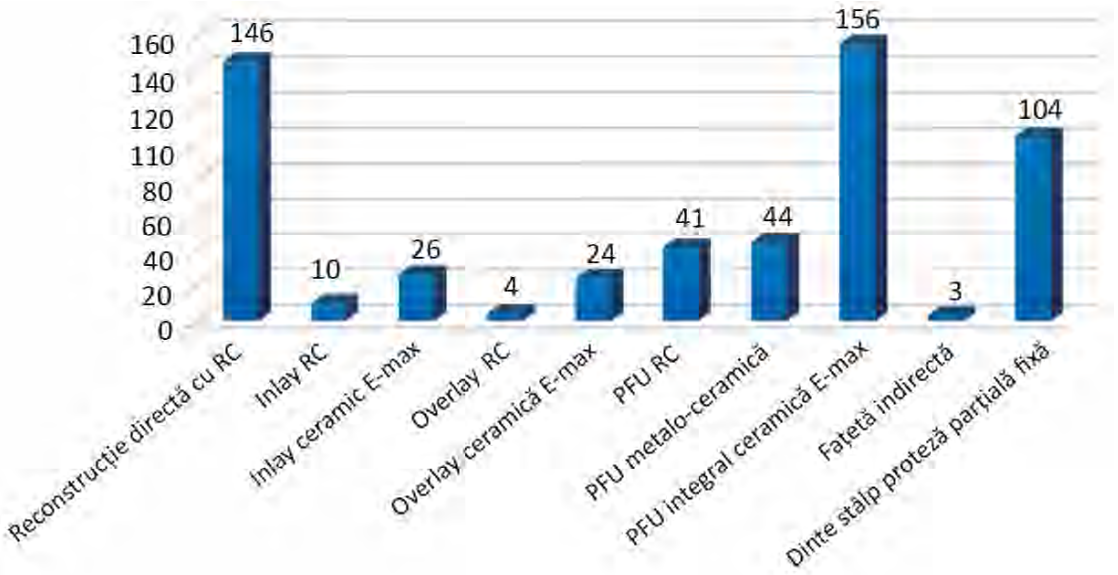

FIGURA 8. Frecvența tipurilor de reconstrucții utilizate pentru reconstrucția dinților devitali

vat umătoarele reconstrucții: reconstrucții directe din rășini compozite, inlay-uri, overlay-uri, proteze fixe unidentare, fațete indirecte și proteze parţiale fixe. Rezultatele arată că cele mai multe reconstrucții sunt de tipul coroanelor de acoperire integral ceramice (156), reconstrucții directe cu rășini compozite (146), proteze parțiale fixe (104), urmate de restul tipurilor de reconstrucții (Fig. 8).

Cazurile incluse în studiu au fost ţinute sub supraveghere o perioadă medie de 9 luni.

Un aspect important al studiului a fost să aflăm care sunt accidentele care se petrec cel mai des şi care este frecvenţa lor. Din totalul de 566 de dinţi devitali reconstituiți, doar 21 au înregistrat un anumit tip de accident, fie fractura reconstrucției (2 cazuri), fie descimentare (19 cazuri) (Fig. 9).

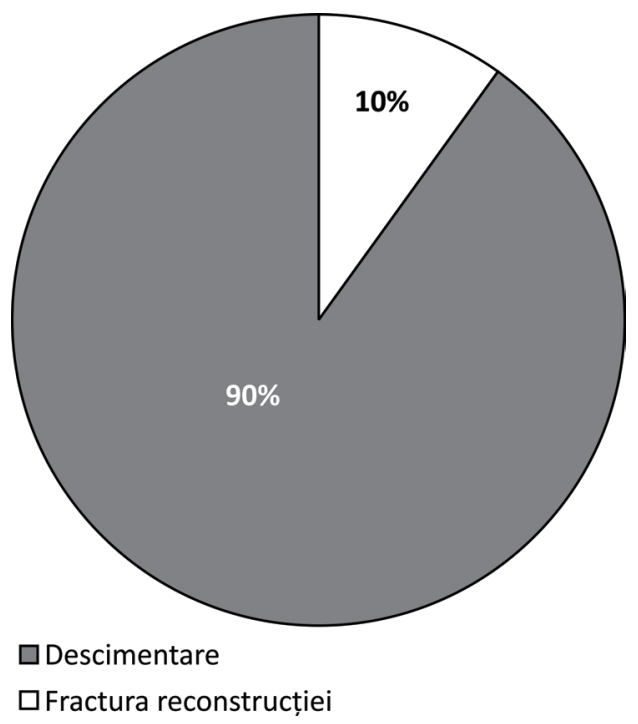

FIGURA 9. Frecvența tipului de accident petrecut la nivelul reconstructiilor
Doar două tipuri de reconstrucții au prezentat fractură în egală măsură: coroanele de înveliș din rășini compozite și coroanele de înveliş integral ceramice (Fig. 10).

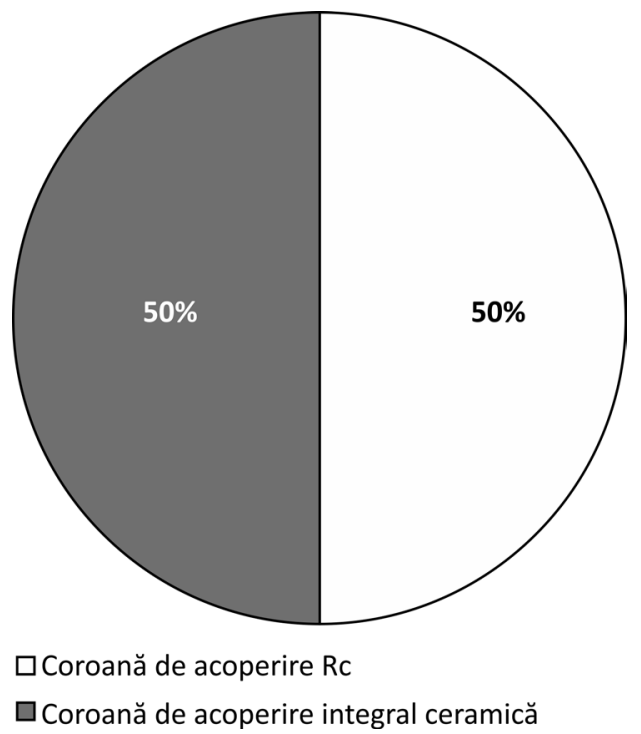

FIGURA 10. Frecvența tipurilor de reconstrucții fracturate

Distribuția accidentelor produse în funcție de tipul de dinte ne arată că majoritatea accidentelor s-au produs la nivelul dinților de pe arcada maxilară (Fig. 11).

S-a constatat faptul că majoritatea accidentelor au fost produse la nivelul dinţilor frontali (67\%) și doar 33\% la nivelul dinților laterali (Fig. 12).

Un alt aspect urmărit în legătură cu accidentele produse a fost de a evidenţia pe ce tip de reconstrucție s-au produs: $38 \%$ la nivelul retentorilor în proteze parțiale fixe din rășini compozite, $24 \%$ la nivelul co- 


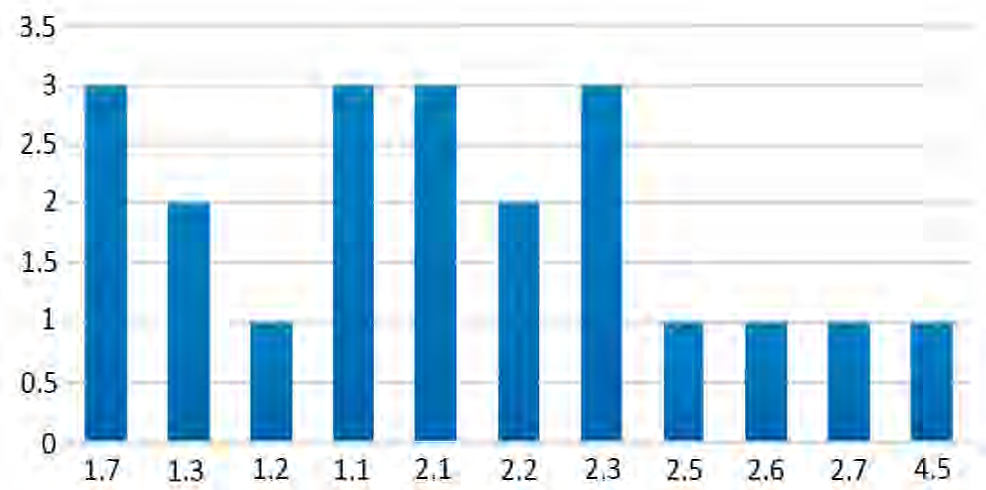

FIGURA 11. Distribuția accidentelor produse în funcție de dinte

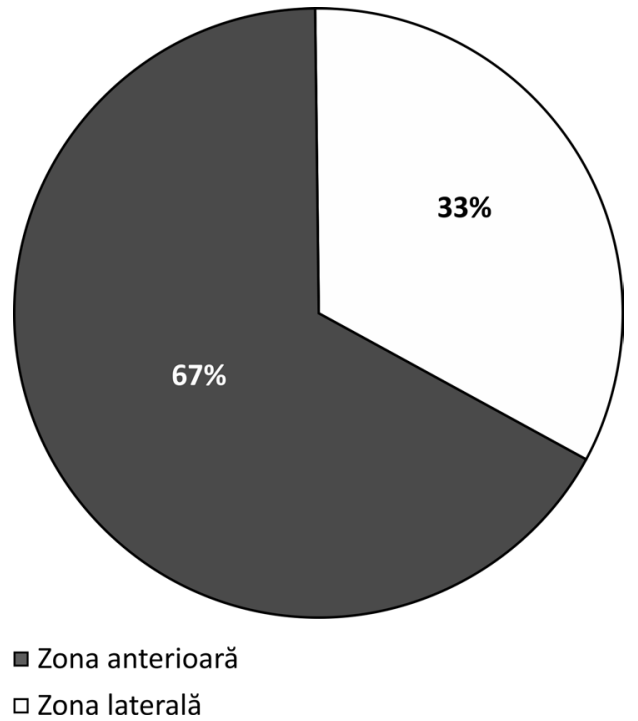

FIGURA 12. Frecvența accidentului în funcție de localizarea dinților

roanelor de înveliș din rășini compozite, 19\% la nivelul retentorilor în proteze parțiale fixe reconstituiți prin tehnica Scutan, 14\% la nivelul coroanelor de înveliș metalo-ceramice și 5\% la nivelul coroanelor de înveliș integral ceramice (Fig. 13).

\section{DISCUṬII}

La ora actuală, există multe studii de specialitate care au testat caracteristicile și supravieţuirea în timp a reconstrucțiilor protetice la nivelul dinților trataţi endodontic, atât in vivo, cât şi in vitro. Principala indicaţie de reconstrucţie a dinţilor trataţi endodontic, conform clinicienilor (în proporţie de 94\%), este de a realiza coroane de înveliş pe aceşti dinţi, cu scopul de a scădea riscul de fractură a dintelui și de a scădea frecvența eșecurilor ce țin de reconstrucție [5]. Rezultatele acestui studiu arată că cele mai multe reconstrucții sunt de tipul coroanelor de acoperire, în special al celor integral ceramice.

De asemenea, există date suficiente pentru a stabili clar obligaţia clinicienilor de a alege între realizarea unei coroane de înveliş sau a unei obturaţii coronare din răşini compozite pe dinţii devitali. Așadar, se ia o decizie în funcţie de circumstanţele cazului, de preferinţele pacientului şi de experienţa medicului dentist [6]. Conform rezultatelor obținute în studiul de faţă, de asemenea, cele mai practicate

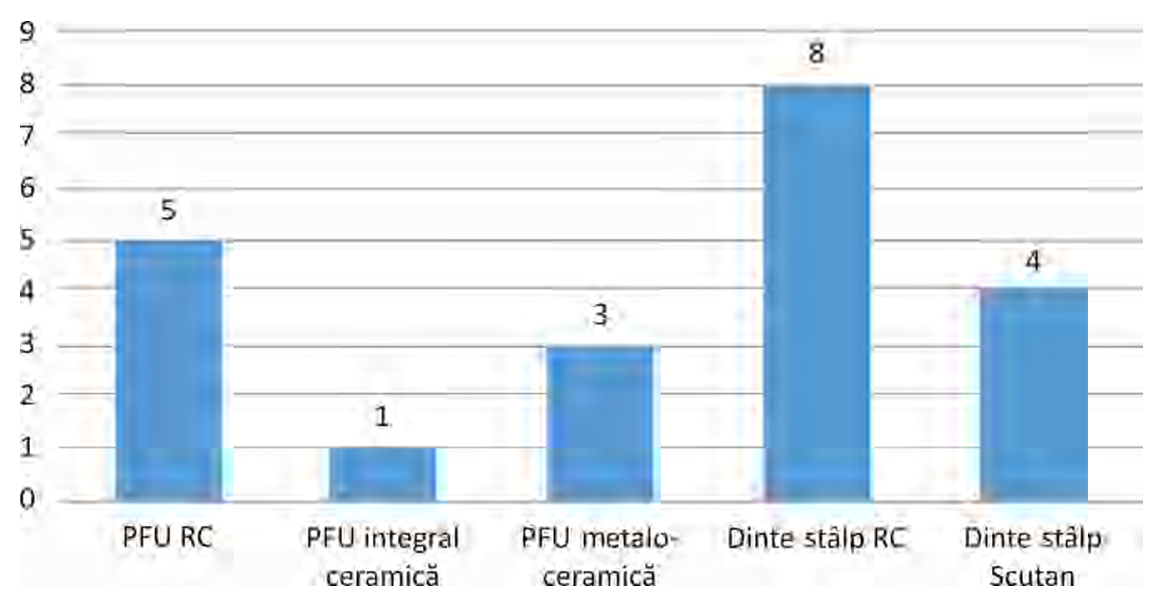

FIGURA 13. Frecvența accidentelor produse în funcție de tipul de reconstrucție 
reconstrucții au fost de tipul reconstrucțiilor directe cu răşini compozite sau al coroanelor de acoperire.

Concluzia unui studiu realizat de Monaco şi colab. pe 32 de molari trataţi endodontic şi apoi reconstituiţi cu overlay-uri din compozit este că succesul este influenţat de faptul dacă aceşti dinţi au fost sau nu ranforsaţi cu pivoţi din fibră de sticlă. Astfel, molarii ranforsaţi şi apoi reconstituiţi cu overlay-uri compozite prezintă o mai mare rezistenţă a reconstrucției sau la fractura dintelui [7]. În studiul de față, s-a observat, de asemenea, cea mai mare frecvență a overlay-urilor pe molari. Deși doar $14 \%$ dintre cazurile reconstituite cu overlayuri din răşini compozite au fost reprezentate de dinţi ranforsați, nu s-au regăsit cazuri cu accidente de tipul fracturii dintelui sau al reconstrucției.

Conform rezultatelor unui studiu realizat de Sequeira-Byron şi colab. pe dinţi trataţi endodontic (premolari şi molari), pe o perioadă de trei ani, se dovedeşte faptul că nu există o diferenţă semnificativă în ceea ce priveşte succesul reconstituirii dinţilor indirect cu coroane metalo-ceramice sau cu răşini compozite [8]. Din studiul de față, a reieșit faptul că au prezentat o rată mai mică de accidente (14\%) coroanele de acoperire metalo-ceramice față de coroanele din răşini compozite $(38 \%)$. Decizia de a reconstitui printr-o metodă sau alta se ia în funcţie de experienţa medicului şi de cantitatea de structuri dentare coronare restante după tratarea leziunilor carioase şi în urma tratamentului endodontic.

În studiul realizat de Rinke şi colab., rata de succes a coroanelor de acoperire metalo-ceramice şi zirconiu, la nivel molar, a fost evaluată folosind testele Kaplan-Meier (pentru evaluarea ratei de supravieţuire şi a ratei de succes) şi regresia Cox (pentru tehnica de fabricare). Rezultatele au arătat cinci eşecuri totale (trei la nivelul coroanei metaloceramice şi două la nivelul coroanei din zirconiu). De asemenea, există diferenţe semnificative între rata de succes şi de supravieţuire între cele două tipuri de tehnici de fabricare, favorabile pentru cele integral ceramice [9]. Prezentul studiu a dovedit şi el acest lucru, procentajul de accidente produse la nivelul coroanelor de acoperire integral ceramice fi- ind de doar 5\% comparativ cu cele metalo-ceramice, de 14\%. Acest lucru poate fi explicat prin particularitățile cimentării adezive.

\section{CONCLUZII}

Cercetarea și studiul realizat în lucrarea de faţă dovedesc importanţa ranforsării cu pivoți din fibră de sticlă a dinților devitali, pentru a le reda rezistenţa. De asemenea, cele mai frecvente restaurări se regăsesc la nivelul dinților laterali, atât la arcada maxilară, cât și la cea mandibulară.

În ceea ce privește legătura dintre tipul de reconstrucție şi ranforsarea dinţilor trataţi endodontic, reiese faptul că este dependentă de cantitatea de structură dentară sănătoasă rămasă la nivelul dinților devitali. Astfel, cu cât o reconstrucție este mai extinsă, cu atât crește necesitatea de a ranforsa dintele. De asemenea, am observat că, în situația unei structuri dentare sănătoase suficiente restante, se preferă reconstrucția prin intermediul inlay-urilor sau overlay-urilor, pe principiul stomatologiei minimum invazive.

Un alt aspect urmărit este reprezentat de distribuţia accidentelor produse în funcţie de tipul de dinte, observându-se că majoritatea accidentelor s-au produs la nivelul dinţilor de pe arcada maxilară și la nivelul dinților frontali. De asemenea, rezultatele statistice au relevat că tipul de material folosit pentru reconstrucție influențează rata de supraviețuire a acestora, cele mai bune rezultate obținute fiind pentru reconstrucțiile din ceramică integrală.

Aspectele clinice legate de reconstrucția dinților devitali sunt complexe: corectitudinea tratamentului endodontic, tipul de dinte, ranforsarea dintelui, tipul de reconstrucție, pregatirea mediculuiși a tehnicianului dentar, dar și nevoile pacientului. Prin urmare, nu se poate indica un indica un protocol standardizat.

\section{Mențiune}

Toți autorii au contribuție egală în realizarea acestui articol.

\section{BIBLIOGRAFIE}

1. Ibrahim AM, Richards LC, Berekally TL. Effect of remaining tooth structure on the fracture resistance of endodontically-treated 
2. Mount GJ, Hume WR. Conservarea și restaurarea structurii dentare. Editura All Education. București, 1999.

3. Jotkowitz A, Samet N. Rethinking ferrule - a new approach to an old dilemma. Br Dent J. 2010 Jul 10;209(1):25-33.

4. Juloski J, Radovic I, Goracci C, Vulicevic ZR, Ferrari M. Ferrule effect: A literature review. J Endod. 2012 Jan;38(1):11-9.

5. McCracken MS, Louis DR, Litaker MS. Treatment recommendations for single-unit crowns: Findings from The National Dental PracticeBased Research Network. J Am Dent Assoc. 2016 Nov;147(11):882890.

6. McReynolds D, Duane B. Insufficient evidence on whether to restore root-filled teeth with single crowns or routine fillings. Evid Based Dent. 2016 Jun;17(2):50-1.
7. Monaco C, Arena A, Scotti R, Krejci I. Fracture Strength of Endodontically Treated Teeth Restored with Composite Overlays with and without Glass-fiber Reinforcement. J Adhes Dent 2016; 18(2):143-9

8. Fedorowicz Z, Carter B, de Souza RF, Chaves CA, Nasser M, Sequeira-Byron $P$. Single crowns versus conventional fillings for the restoration of root-filled teeth. Cochrane Database Syst Rev. 2012 May 16; (5):CD009109.

9. Rinke S, Kramer K, Burgers K, Roediger M. A practice-based clinical evaluation of the survival and success of metal-ceramic and zirconia molar crowns: 5-year results. J Oral Rehabil. 2016 Feb;43(2):136-44. 